\title{
National Health Security Policy in Indonesia: A Narrative Review from Law Perspective
}

\author{
Arief Budiono*(iD, Absori Absori, (D), Syaifuddin Zuhdi (iD, Kurnianingsih Kurnianingsih (D), Inayah Inayah, (D), Moh Indra Bangsawan (D), \\ Wardah Yuspin (D)
}

Department of Law, Faculty of Law, Universitas Muhammadiyah Surakarta, Surakarta, Indonesia

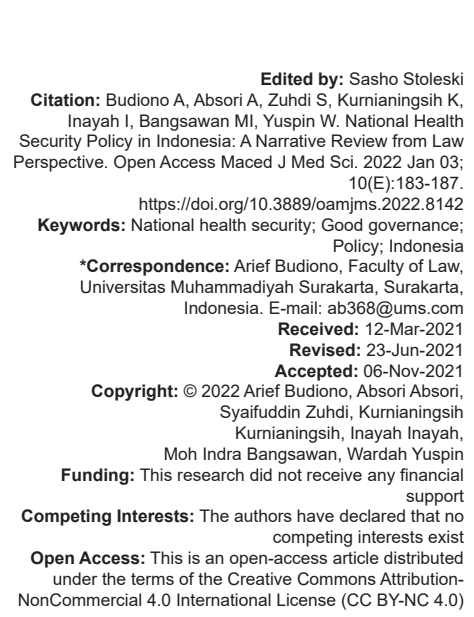

Abstract

BACKGROUND: The Republic of Indonesia's 1945 Constitution Article 28H clause (3) on the Rights to Social Security, Law No. 40 of 2004 on the National Social Security System, and Law No. 24 of 2011 on the Healthcare and Social Security Agency stipulate that everyone has the right for social security to achieve an adequate standard of living and to increase their dignity. This is to create a prosperous and just society.

AIM: This research aims to describe the current National Health Security (NHS) policy as well as the good governance-based NHS policy.

METHODS: This is normative legal research by doing literature analysis and/or secondary data. This descriptive research uses the statute and conceptual approaches.

RESULTS: Results show that the Indonesian NHS is based on Law No. 24 of 2011 on the Social Security Agency (Badan Penyelenggara Jaminan Sosial). It has not been implemented optimally due to lack of accommodation of the good governance principles, including legal certainty, benefit, non-partiality, prudence, non-abuse of authority, transparency, public interest, and good service.

CONCLUSION: Thus, the government needs to optimize the application of these principles in managing the NHS policy to provide the best services for the people.

\section{Introduction}

Indonesia's legal, economic, social, and political issues often happen due to the government's failure in undergoing its role well. It is as if the state is absent to the weak and the underprivileged [1], even though it has the power to use its laws and authority to bring prosperity. The state must guarantee social welfare as well as allocate resources, services, and opportunities for all citizens [2]. As the highest public power, the state has the authority to create laws to achieve social prosperity in the aspects of health, social security, etc. In Germany, this view is known as recht its was demvolkenatz or "the law is what is beneficial for society" [3]. Apart from the law, state leaders or people's representatives must also show examples by working for the sake of public interests [4].

Health is society's primary need. It is the greatest capital to achieve welfare. To be effective, public health services must be guaranteed by the government. Healthcare security is a form of governmental health protection for its participants to fulfill their basic health needs [5]. In reality, people are only perceived as objects to develop the state's healthcare programs. Thus, many issues occur, such as inequality of access, discrimination, and lack of program efficiency [6]

Thus, the Indonesian government created the Health Security Program for the poor. As it is ineffective, the government established the National Health Security (NHS) through BPJS Health (Badan Penyelenggara Jaminan Sosial Kesehatan/Healthcare and Social Security Agency) in 2014. Even so, not all citizens have become participants. The health services are not equally distributed and are uneven, and there are suboptimum referral and payment systems. This causes health injustice among various social groups [7].

BPJS Health experienced a deficit of Rp. 9.1 trillion in 2018 and Rp. 15 trillion in 2019 [8]. Thus, its premiums were increased based on Presidential Decree No. 64/2020, decreasing the deficit into Rp. 184 billion. However, it risks people having difficulties in paying the premiums; thus, risking their access to health services.

The $1^{\text {st }}$ gap between the classes is on the comfortable room and with the more standard of health services in comparation of $2^{\text {nd }}$ class and $3^{\text {rd }}$ class. The $1^{\text {st }}$ class received rooms with 2 or 3 patient and able to choose the VIP room with additional payment. The $2^{\text {nd }}$ class was $4-5$ and $3^{\text {rd }}$ Class received room with minimum six 
patients [8]. In term of comfortable for patient and family, then the $1^{\text {st }}$ class is superior. This gap also had an effect some of $3^{\text {rd }}$ class was rejected by hospital and health facility with the reasons the room was full and unable to received $3^{\text {rd }}$ class of NHS because the payment from NHS insufficient to give health services thus the hospital and health service give cross subsidy for $3^{\text {rd }}$ class [9].

$2^{\text {nd }}$ Gap between the class was doctor services. $1^{\text {st }}$ class had of priority of the health services from the health facility or Hospitals rather than $2^{\text {nd }}$ and $3^{\text {rd }}$ class. This gap of services is because the hospital get much more money for facilities for the $2^{\text {nd }}$ class and $3^{\text {rd }}$ class. In some of hospital and health facility services for $2^{\text {nd }}$ class and $3^{\text {rd }}$ class not too good. An Example visiting Doctor was too short and too late and not comprehensive as the $1^{\text {st }}$ class.

The $3^{\text {rd }}$ gap was for food because for the $1^{\text {st }}$ class NHS was paid more than $2^{\text {nd }}$ and $3^{\text {rd }}$ class for room and the $1^{\text {st }}$ class room had better and nutrition food than $2^{\text {nd }}$ and $3^{\text {rd }}$ classes. With more nutritious food, then $1^{\text {st }}$ class patient could recovery much more fast. The $4^{\text {th }}$ gap is come for personal treatment from medical personnel. Many studies had shown several cases occurred because the personal had underestimate thus lead downgraded treatment for the $3^{\text {rd }}$ class patient [10].

Thus, the program needs to be improved to avoid burdening society. As a legal public agency, it must be directed to good governance, as mandated by Law No. 30 of 2014 on Governmental Administration that contains the Principles of Good Governance. Apart from written legal regulations, these principles become the governmental ethical norms that must be complied with.

\section{Methods}

This is normative legal research by doing literature analysis and/or secondary data. This descriptive research uses the statute and conceptual approaches. First, we analyze various regulations concerning health security and other organic laws on the research object. Then, we also analyze by the good governance perspective. It is carried out using critical and predictive analyses to find the advantages and disadvantages of the former NHS policy model. Then, the writer predictively reformulates a new model of health security that is deemed to be more effective and more suitable to the Indonesian society.

\section{Results}

In Indonesia, social security is established based on Law No. $28 \mathrm{H}$ clause (3) on Social Security
Rights and Article 34 clause (2) of the 1945 Constitution, and Decision of the People's Representative Assembly No. X/MPR/2001, which mandates the President to form an integrated and comprehensive National Social Security System (NSSS). Constitutionally, the NSSS is the responsibility of the government, but it is bestowed to the BPJS as a legal agency. Institutionally, BPJS is under the authority of the president based on Article7 clause (2) of the Law on BPJS. This makes BPJS have the same power as the ministry. The BPJS is divided into two, namely BPJS Health (that establishes health security) and BPJS Workforce (that establishes occupational safety security, retirement security, etc.), as stipulated in Law No. 24 of 2011. The NHS is established by the BPJS on January 1, 2014. All citizens are expected to become participants of this program, to fulfill their basic health needs [11].

Some parties dispute some stipulations of the 2011 BPJS Law. One of its articles has even become a judicial review material in the Constitutional Court as follows:

A state that only regulates private matters such as fraud, theft, and contract is narrow. The state must consider the chance for the vertical distribution of welfare. According to Nozick's social welfare theory, he accepts that vertical is possible when, "Compensation is paid. only in the amount that will equal" [12]. According to this theory, the state's free resource redistribution in society without the approval of everyone will lead to slavery, as taxpayers must contribute to the welfare of other people whom they do not know of [13]. Nozick's thought on social security's role in the state is contrary to the concept of the Indonesian state [14]. The state is not involved in thinking about social welfare, thus, Nozick's opinion is deemed as strange.

BPJS Health has projected the deficit based on three periods based on the premiums: First, between January to March 2020, the premiums are based on the Presidential Decree No. 75/2019 on Health Security. Second, between April and June 2020, the decreased premiums are paid based on Presidential Decree No. 82/2018. Third, between July to December 2020, where the premiums increased and are paid based on Presidential Decree No. 64/2020. It is projected that by the end of 2020, BPJS Health experiences a surplus of Rp 2.56 trillion rupiahs [15].

The universal health coverage in Indonesia faces issues concerning target achievement, lack of funds and service quality. In Thailand, however, the government is able to maintain the health service quality in their hospitals [16].

There are internal and external factors that inhibit poor people's access to health services [17]. The internal factors are lack of awareness on healthy living behaviors, lack of interest to visit community health centers, lack of understanding on the health insurance card, and lack of participation in the available health 
services. The external factors (sourced from the health service providers) are: Inadequate number and quality of health workers and health services and health workers' placement are not according to the situation in the field, lack of health information systems, lack of health funds, and lack of health service facilities. Furthermore, some health workers violate the health standard regulation. It lowers the health service quality [18], though the state must fulfill the rights of its people [19] including the rights to obtain health services.

The global socio-economic inequalities impact differences in health quality. Unequal distribution of health services is also caused by health financing [20]. Everyone wants to be healthy, but not everyone can afford it. Departing from that assumption, an important variable in the effort to secure health is to guarantee the provision of health service funds [21]. The NHS through BPJS that aims to grant equal access to health for all Indonesians is not problem-free. One of the problematic aspects is its basic regulation, namely, Law No. $24 \mathrm{f}$ 2011 on BPJS (Figure 1).

\section{Discussion}

The development of democracy and globalization created political innovation based on transparency, participation, collaboration, and legality. A public service paradigm that supports them is good governance, where the government governs transparently. This is because the public has the right to observe officials. Law No. 14 of 2008 on Public Information Transparency is the legal standing of the public institutions' obligation to provide valid public information and the public's right to access them [22].

To achieve good governance, the government must uphold the General Principles of Good Governance according to Law No. 28 of 1999 on the Governmental Establishment that is Free from Collusion, Corruption, and Nepotism. Clause (6) of this law states that the Good Governance principles uphold decency, compliance, and legal norms, to create a government that is free from collusion, corruption, and nepotism. Article 10 clauses (1) and (2) of Law No. 30 of 2014 on Governmental Administration describes that normatively, the principles of good governance consist of the legal certainty principle, benefit principle, non-partiality principle, prudence principle, non-abuse of authority principle, transparency principle, public interest principle, and good service principle. Other principles may be applied so long as they are used as the judicial basis of assessment and are written in a permanently binding legal court verdict. Thus, these principles also bind juridical-formally [23].

The Good Governance concept emerges due to the public dissatisfaction with governmental performance. It is implemented step-by-step according to the capacity of the government, civilians, and market mechanism. A strategic choice to implement it is through public services [24], namely, all types of services in the forms of goods and services that are carried out by central and regional governmental institutions, at the central or regional state-owned business enterprises. One of them is through the BPJS that is a legal entity that establishes the people's social security program so they may live well based on the principles of humanity, benefit, and social justice [25]. Research results show that good governance significantly influences performance. Thus, good governance in BPJS will improve its performance [26]. This is to anticipate the burden of health services due to failure in accessing early treatment, which causes high morbidity and people's consumption rate of health service resources, as stated by Andre and Velasquez [27].

Good governance is implemented step-by-step according to the capacity of the government, civilians, and market mechanism. Individuals' responses to BPJS Health may differ. These responses may influence people's way of thinking as follows (Figure 2):

The image shows that people with low participation and low support will change slowly or even become passive. People with high participation and low support will inhibit good governance as they are sceptical and protective. They oppose processes and try to discredit efforts carried out. Then, people with high participation and high support strive for changes and consequently implement the changes that happen [28].

It is difficult to make people achieve the high position and high support quadrant as the government's policies do not accommodate the principle of nonpartiality among the good governance principles to people who lack fulfillment of daily needs. This is shown by the government's policy to increase BPJS premiums by almost $100 \%$ to independent Class I and Class II as issued in the Presidential Decree No. 64 of 2020 on the Second Amendment of the Presidential Decree No. 82 of 2018 on Health Security. It stipulated that from July to December 2020, Class l's premium increased to Rp. 150.000 from Rp. 80.000; that of Class II increased to Rp. 100.000 from Rp. 51.000; that of Class III increased to Rp. 42.000 from Rp. 25.500. However, the government subsidized Class III by Rp. 16.500, thus, they only pay Rp. 25.500. Even so, in 2021 the subsidy decreased to Rp. 7.000 , so participants must pay Rp. 35.000. This decrease of subsidy is due to the polemic of BPJS' deficit, though the government should not only depend on the people's payment of premiums but instead improve the management of BPJS [29].

Another suboptimum implementation of a good governance principle in BPJS health is the prudence principle. Decision of the Supreme Court No. 7/P/HUM/2020 cancelled the BPJS premiums for unoccupied participants and participants who are non-wage workers after granting the judicial review on 
Presidential Decree No. 75 of 2019 on the Amendment of Law No. 82 of 2018 on Health Security [30]. Ironically, after that cancellation of premium fees, the government issued Presidential Decree No. 64 of 2020 on the Second Amendment of the Presidential Decree No. 82 of 2018 on Health Security that again increases the BPJS Health premium fees. This shows the government's imprudence in understanding the decision of the Supreme Court.

Some other good governance principles that are not yet implemented well are the principles of public interest and the principle of services. The Decision of the Supreme Court on the cancellation of Presidential Decree No. 75 of 2019 on the Amendment of Law No. 82 of 2018 on Health Security opines that the increase of premiums for unoccupied participants and participants who are non-wage workers as stipulated in Article 34 clause 1 and 2 of Presidential Decree No. 75 of 2019 is sociologically against society's interest. It shows the concerning institutions' incapability to coordinate and to carry out their tasks.

Another suboptimum principle implementation is the principle of benefit. The Supreme Court regard that the increase of BPJS -premi during the pandemic is not appropriate as it does not fulfill a sense of justice in society. Thus, Presidential Decree No. 75 of 2019

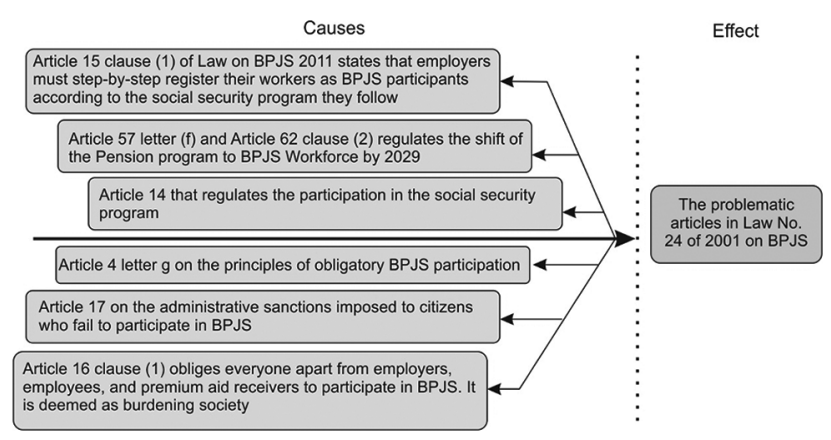

Figure 1: Problematic articles in Law No. 24 of 2011 on BPJS[31]

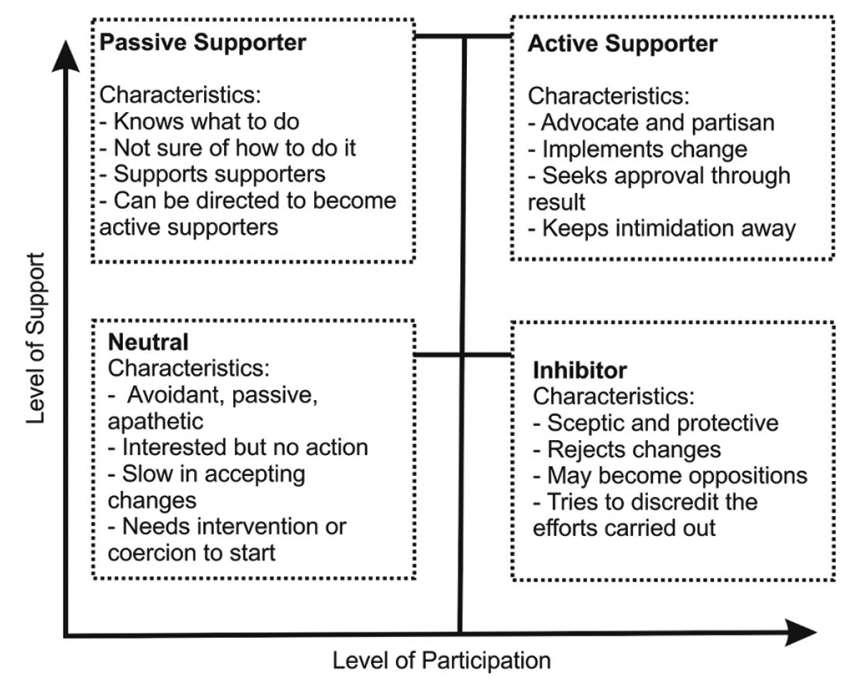

Figure 2: Four groups of the change of thought paradigm [25] cannot burden society with increasing fees. Instead, BPJS should increase its benefit to society [32].

Thus, the government needs to optimize the implementation of the eight principles of good governance in managing BPJS Health. It is not simple as it requires the awareness of all establishments to provide the best service for society.

\section{Conclusion}

In Indonesia, social security is established based on Law No. $28 \mathrm{H}$ clause (3) on Social Security Rights and Article 34 clause (2) of the 1945 Constitution, and Decision of the People's Representative Assembly No. X/MPR/2001, which mandates the President to form an integrated and comprehensive NSSS. Through Law No. 24 of 2011, the government stipulated the NSSS be established by BPJS, consisting of BPJS Health and BPJS Workforce. The NSSS policy is not optimally implemented as the principles of good governance have not been accommodated. For instance, the Presidential Decree No. 64 of 2020 stipulates the increase of the BPJS Health premium fees, though the Decision of the Supreme Court 7/P/HUM/2020 and the Presidential Decree No. 75 of 2019 has revoked it. Thus, the government needs to optimize the implementation of the good governance principles in running BPJS Health to provide the best services for society.

\section{References}

1. Budiono A, Izziyana WV. National social security system implementation policy through the healthcare and social security agency with the insurance system. Law Pro Just. 2011;2(1):34-47.

2. Fabre $\mathrm{C}$. To deliberate or to discourse: I that the question? Eur Polit Theor J. 2003;2(1):107-15.

3. Budiono, A., Absori, Ngestiningrum, A. H., \& Nugroho, H. S. W. Pseudo national security system of health in Indonesia.Indian J Public Health Res Dev. 2018;9(10):556. doi:10.5958/0976-5506.2018.01404.3.

4. Marwoto BJ, Witdarmono. Proverbia Latina. Vol. 22. Jakarta: Kompas; 2004.

5. Susniwati S, Kurhayadi K. Collaboration of the healthcare and social security agency management in handling the deficit of its programs in Bandung City. MEA. 2020;4(2):350.

6. Widianto AA. Bridging poor people's accessibility to health services through local institutions. Reflektif. 2016;8(1):53.

7. Saputra M, Marlinae L, Rahman F, Rosadi D. The national health security program from the aspect of health service human resources. KEMAS. 2015;11(1):33

8. Widyanoko A, Astuti P, Yuwanto $Y$. Analysis of the service quality of the BPJS national health insurance program health at the Madiun city regional general hospital. J Polit Gov Stud. 2014;3(4):91-105. 
9. Suhartoyo S. Hospital claims to BPJS health related with inpatient with INA-CBGs system. Adm Law Gov J. 2018;1:79-92.

10. Ali M. Obstacles to TQM success in health care systems. Int J Health Care Qual Assur. 2013;26(2):147-73. https://doi. org/10.1108/09526861311297352

PMid:23534150

11. Firdaus KK, Wondabio LS. Analysis of health premium and burden to evaluate the health security program. ASET. 2019;11(1):148.

12. Larasati $\mathrm{N}$. The national health security program quality of services to guarantee health protection for healthcare and social security agency members in soewandhie hospital, Surabaya. Sumber. 2014;75(44): 154

13. Nozick R. Anarchy, State and Utopia. Vol. 133. New York: Basic; 1999.

14. Nozick R. Anarchy, State, and Utopia. Vol. 88. Oxford: OUP; 1974.

15. Amal B. Social Welfare and Progressive Law Enforcement. Jakarta: KHI; 2014.

16. Tempo. No longer deficit, the Healthcare and Social Security Agency is Believed to Experience a Surplus of Rp. 256 Trillion 2021. Available from: https://bisnis.tempo.co/read/1387317/taklagi-defisit-bpjs-kesehatan-diyakini-bakal-catat-surplus-rp-256triliun/full\&view=ok [Last accessed on $2021 \mathrm{Feb}$ 14].

17. Mutiarin D. Evaluation of universal health coverage policy: A comparison study between Indonesia and Thailand. UMY. 2015;7:1-98.

18. Ferdinandus. Poor People's Access to Health Services in Bolaang Mongondow Regency Thesis. Yogyakarta: UGM; 2008.

19. Dimyati K, Nashir H, Elviandri E, Absori A, Wardiono K, Budiono A. Indonesia as a legal welfare state: A prophetictranscendental basis. Heliyon. 2021;7(8):1-8.

20. Bangsawan M, Absori A. Implementation of Land Certification and its Implication to Social Welfare. Thesis. Surakarta: UMS; 2019.
21. World Health Organization. Universal Health Coverage. Geneva: World Health Organization; 2021. Available from: https://www. who.int/health-topics/universal-health-coverage\#tab=tab_1

22. Izziyana $\mathrm{WV}$, Harun $\mathrm{H}$, Absori A, Kelik W, Nugroho HS, Budiono A. Health insurance for Indonesian migrant workers. Medico Legal Update. 2019;19(1):189-92.

23. Suratno SB. Formulating policies based on good governance policies. Lentera Hukum. 2017;4(3):172.

24. Maryam SN. Achieving good governance through public services. JIPSI. 2017;6:2.

25. Budiono A, Absori A, Harun $H$, Nugroho HSW, Dimyati $K$, Ngestiningrum $\mathrm{AH}$. The Anachronism of the Indonesian Social Security Policy in Health. Medico Legal Update. 2013;19(1), 229-233. https://doi.org/10.37506/mlu.v19i1.919.

26. Thabrany H. Jaminan Kesehatan Nasional (National Health Security). Jakarta: Raja Grafindo Persada; 2016.

27. Maruthappu M, Ologunde R, Gunarajasingam A. Is health care a right? Health reforms in the USA and their impact upon the concept of care. Ann Med Surg. 2013;2(1):15-7. https://doi. org/10.1016/S2049-0801(13)70021-9 PMid:25973184

28. Bennis W, Misch M. $21^{\text {st }}$ Century Organization Reinventing through Reengineering. Jakarta: PPM; 1995.

29. Kumurur V. E-Government implementation encourages the establishment of a good government. EKOTON. 2012;8(2):64.

30. Siagian AH. Blunder of Healthcare and Social Security Agency Premiums. Medan: UMSU; 2019.

31. Budiono A, Absori A, Harun H, Nugroho HS, Dimyati K. The AQ1 ideal management of health insurance for Indonesia according constitution. Calitatea. 2020;21(176):48-50.

32. Budiono A, Absori A, Harun H, Nugroho HS, Dimyati K. The ideal management of health insurance for Indonesia according constitution. Calitatea. 2020;21(176):48-50.

Author Queries???

AQ8: Kindly check and confirm the 31 and 32 references are same. 